\title{
IMPROVING STUDENTS' READING COMPREHENSION THROUGH THINK-PAIR-SHARE (TPS) TECHNIQUE
}

\author{
Mila Nuryani ${ }^{1}$, Emi Rosmiati ${ }^{2}$ \\ ${ }^{1}$ IKIP Siliwangi \\ ${ }^{2}$ IKIP Siliwangi \\ ${ }^{1}$ mnuryani95@gmail.com, 2 emihanif3@gmail.com
}

\begin{abstract}
The aim of this research is to improve students' reading comprehension at the eleventh grade of SMA Mathla'ul Anwar using the think-pair-share technique. The writers implementing this method is to make students easier to understand in a reading activity in the class through discussion and sharing information with their friends. The method of the research is classroom action research (CAR), the research has been carried out in three cycles to achieve students' improvement in reading comprehension. The mean score in the first cycle is 59.6. In the second cycle is 67.5 and the third cycle is 77. The mean score of the third cycle shows that the think-pair-share technique has succeeded in improving students' reading comprehension.
\end{abstract}

Keywords: TPS, Reading Comprehension, CAR

\section{INTRODUCTION}

Language has a very important role in the creation of communication either orally or in writing, and as a practice to develop thinking skills. Then, the use of language can determine the quality of all forms of communication individually or in groups. English is a language used by all countries in the world as an international language. Then, mastery of English is very necessary as a supporting facility in realizing the creation of good and widespread communication.

In Indonesian, English is a foreign language that is widely used in various fields, including economics, medicine, law, politics, art and culture, industry, and education.In the field of education, language learning in schools especially English is expected to help students in developing their knowledge, abilities and language skills. There are four skills in English that must be mastered by students, namely Reading skills, Writing skills, Listening skills and Speaking skills.

At all levels of education, Reading skills are the main points that must be mastered by students. Hodgson (Tarigan, 2008) cited in Rosyana, 2015 explained that "reading is a process that is carried out and used by the reader to get the message to be conveyed by the author through the words or written language media". According to Apsari \& Yana (2015), reading is not only important in developing language intuition and determining academic success but also it is important for completing certain task. In reading activities there will be an interaction between the reader and the author. Reading is also always done with understanding. Snow (2002: 11) cited in Sapsuha and Bugis, 2013 define "reading comprehension as the process of simultaneously extracting and constructing meaning through interaction and involvement with written language". 
The purpose of Reading Comprehension in relation to learning in senior high school is that students can read carefully to understand the contents of a text correctly. Reading Comprehension skills must be accustomed to and developed in school. A student must be able to read quickly and understand what he/she is reading.

The reality in the field shows that Reading Comprehension skills at Mathla'ul Anwar Senior High School are still not optimal. It can be proven that when learning English activity, only a few students pay attention correctly. At the time of reading, students only pay attention to the reading spelling without knowing the main idea of the text given by the teacher, students do not get information from the text they read. Therefore, writers will use the TPS technique (thinkpair-share) to improve students' Reading Comprehension skills.

TPS is developed to encourage students' participation in the classroom activities (Lyman, 2005: 1) in Mundriyah and Parmawati (2016). Mc Candlish (2012:2) as cited in Sapsuha and Bugis 2013 states that "Think-Pair-Share is a cooperative discussion that has three parts to the process -student think about a question or an issue, they talk with a partner about their thoughts, then some student's share their discussion and thinking with the class". The writer hopes this method makes students more enthusiastic and diligent in learning.

\section{METHOD}

To support the process in improving students' reading comprehension the writers used a type of Classroom Action Research (CAR) by using (TPS) think-pair-share as a method. (Burns, 2009) stated that the central idea of the action part of action research is to intervene in deliberate ways in the problematic situation in order to bring about changes and, even better, improvements in practice. Based on the description above the writers conclude that Classroom Action Research will help the researcher to solve the problem in the teaching reading process. This research was conducted at eleventh-grade students in Mathla'ul Anwar Senior High School consisting of 33 students as a research subject. According to Kemmis and McTaggart (1998) in Burns (2009) said that "there are four steps in action research. Namely: planning, action, observation, and reflection". The writers used several procedures which is including steps in CAR.

To collect data the writers used Tests, Observation sheet, and Fieldnotes.

a. Test

The test consists of 20 multiple choice items related to analytical exposition text. The value of the comprehension test is obtained by summing all the scores obtained by the students with the Minimum Kriteria Ketuntasan Minimal (KKM). And for the KKM (Kriteria Ketuntasan Minimal) at Eleventh-grade students of Mathla'ul Anwar senior high school 70. Students are said to complete learning if the final score obtained is 70 and it means the teacher can help students improve their reading skills using the Think Pair Share (TPS) method.

The writers calculate the results of students' reading comprehension as follows:

$$
\text { Score }=\frac{(\text { students correct answer })}{(\text { total number of items })} \times 100
$$

(Helmin in Rusdiansah 2010)

The writers will describe the analysis of data taken from the results of students' reading test. The mean score of each student is calculated by using formula as follows: 
Note: $\quad \bar{X}=$ Mean score

$$
\bar{x}=\frac{\sum X}{N}
$$

$\sum X=$ The sum of all score

$\mathrm{N}=$ The total number of the subject. (Gay in Rusdiansah 2010)

The mean score was classified into the following table:

Table 1. Criteria Mean Score

\begin{tabular}{cc}
\hline Rate of Scores & Categories \\
\hline $\mathbf{9 6}-\mathbf{1 0 0}$ & Excellent \\
\hline $\mathbf{8 6 - 9 5}$ & Very Good \\
\hline $\mathbf{7 6 - 8 5}$ & Good \\
\hline $\mathbf{6 6}-\mathbf{7 5}$ & Fairly Good \\
\hline $\mathbf{5 6}-\mathbf{6 5}$ & Fair \\
\hline $\mathbf{3 6}-\mathbf{5 5}$ & Poor \\
\hline $\mathbf{0}-\mathbf{3 5}$ & Very Poor \\
& $\quad$ Mutmainnah in Rusdiansah 2010)
\end{tabular}

b. Observation sheet

The observation sheet is used during teaching and reading activities using a think-pair-share (TPS) technique.

c. Fieldnotes

Field notes are notes that are made when teaching and learning activities are applied. The writers will retrieve data from the students' worksheet then analyze the data.

\section{RESULTS AND DISCUSSION}

\section{Results}

The writer used a type of Classroom Action Research (CAR) by using Think-pair-share (TPS) as a method in improving reading comprehension in analytical exposition. The writers conducted the research in the first cycle is based on the problems in the eleventh grade of Mathla'ul Anwar senior high school.

The first cycle consists of planning, action, observation, and reflection. In the first cycle, the authors applied the learning model using TPS techniques with the steps of Thinking, Pairing, and Sharing.

Based on observations made in the first cycle, the TPS method is still not optimal. Some students still difficult to understand the contents of the text, determine the generic structure of the analytical exposition text, and some students are still not familiar with the think-pair-share technique. Based on these problems, it can be concluded that students' reading comprehension ability with the TPS technique is still not optimal.

The writers calculate the students' score by collecting the students' task in order to get the mean score. The result of the first cycle is not good, the means score of the first cycle is 59.6. It means that the writers must be better in the second cycle because the aim of writers is to reach the means score of 70 . The result of the first cycle can be seen from this table as follow 
Table 2. Students score in cycle 1

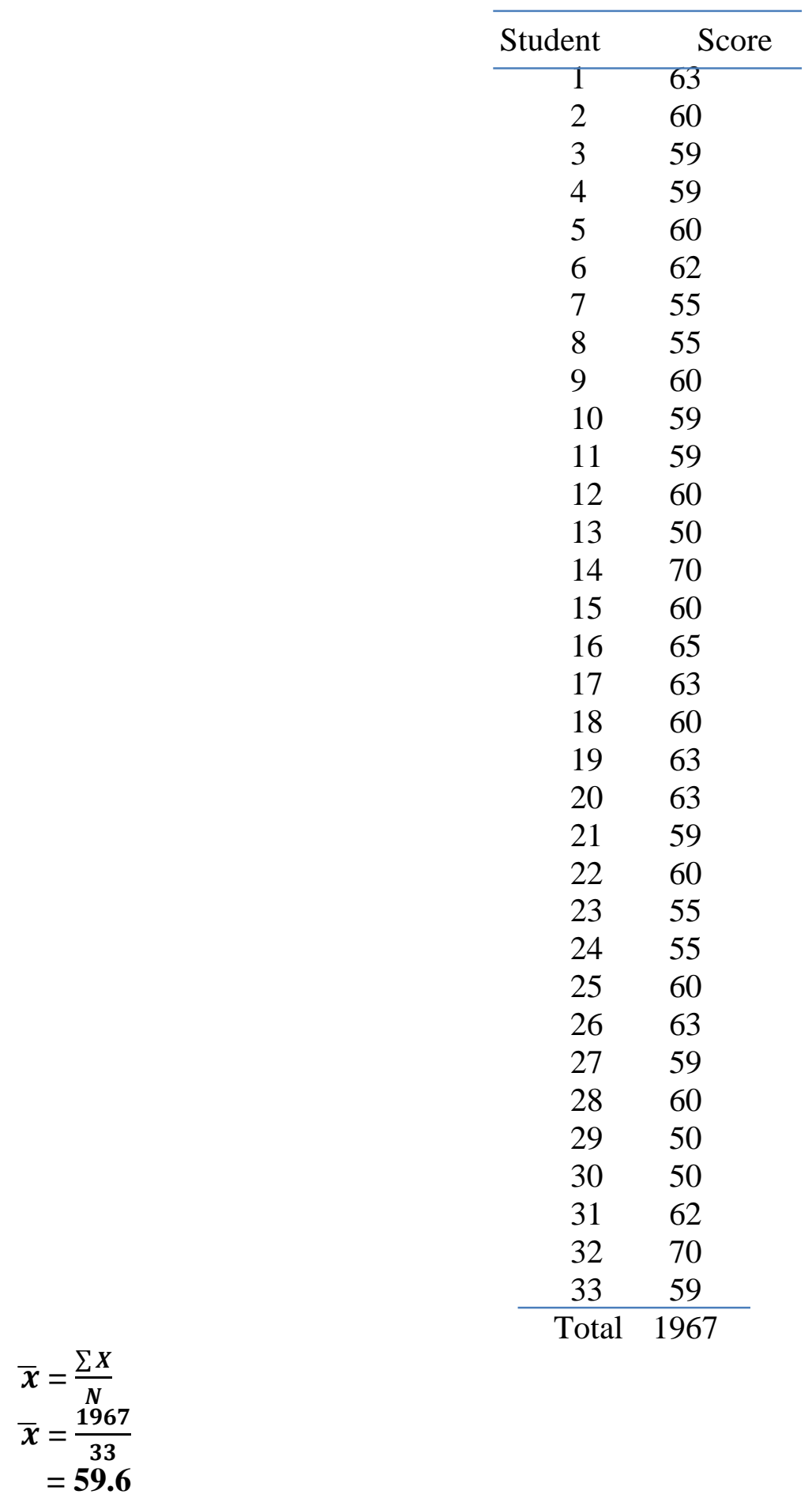

Based on the first cycle, problems that must be solved in the second cycle is that some students still can not understand the contents of the analytic exposition text, determine the generic structure of the analytical exposition text, and some students still do not understand the thinkpair-share technique. Regarding the problem above, the writers conducted the second cycle. The writers explain how to use the think-pair-share technique in analytic exposition text so that students are interested in the process of reading. The results of the second cycle are still not good because the average score of the second cycle is 67.5. The results of the second cycle can be seen from this table as follow 
Table 3. Students score in cycle II

\begin{tabular}{|c|c|}
\hline Students & Score \\
\hline 1 & 67 \\
\hline 2 & 70 \\
\hline 3 & 65 \\
\hline 4 & 67 \\
\hline 5 & 67 \\
\hline 6 & 70 \\
\hline 7 & 65 \\
\hline 8 & 65 \\
\hline 9 & 69 \\
\hline 10 & 65 \\
\hline 11 & 67 \\
\hline 12 & 69 \\
\hline 13 & 67 \\
\hline 14 & 75 \\
\hline 15 & 69 \\
\hline 16 & 70 \\
\hline 17 & 70 \\
\hline 18 & 65 \\
\hline 19 & 65 \\
\hline 20 & 69 \\
\hline 21 & 67 \\
\hline 22 & 67 \\
\hline 23 & 65 \\
\hline 24 & 65 \\
\hline 25 & 67 \\
\hline 26 & 69 \\
\hline 27 & 65 \\
\hline 28 & 70 \\
\hline 29 & 67 \\
\hline 30 & 65 \\
\hline 31 & 69 \\
\hline 32 & 73 \\
\hline 33 & 65 \\
\hline Total & 2230 \\
\hline
\end{tabular}

$$
\begin{aligned}
\bar{x} & =\frac{\sum X}{N} \\
\bar{x} & =\frac{2230}{33} \\
& =67.5
\end{aligned}
$$

On observations in cycle 2 , the implementation of cycle 2 is better than cycle 1 because students more understand the TPS technique and how to use it in reading activities, students can determine the generic structure in the analytical exposition text but students still find it difficult to analyze the main ideas on analytical exposition text. 
Based on the mean score in the first and second cycles, the writers conducted the third cycle. And then the writers give a score on the students' work results. The results are good because the score of students is increasing and the mean score of the third cycle is 77 . The result of the second cycle can be seen from this table as follow:

Table 4. Students score in cycle III

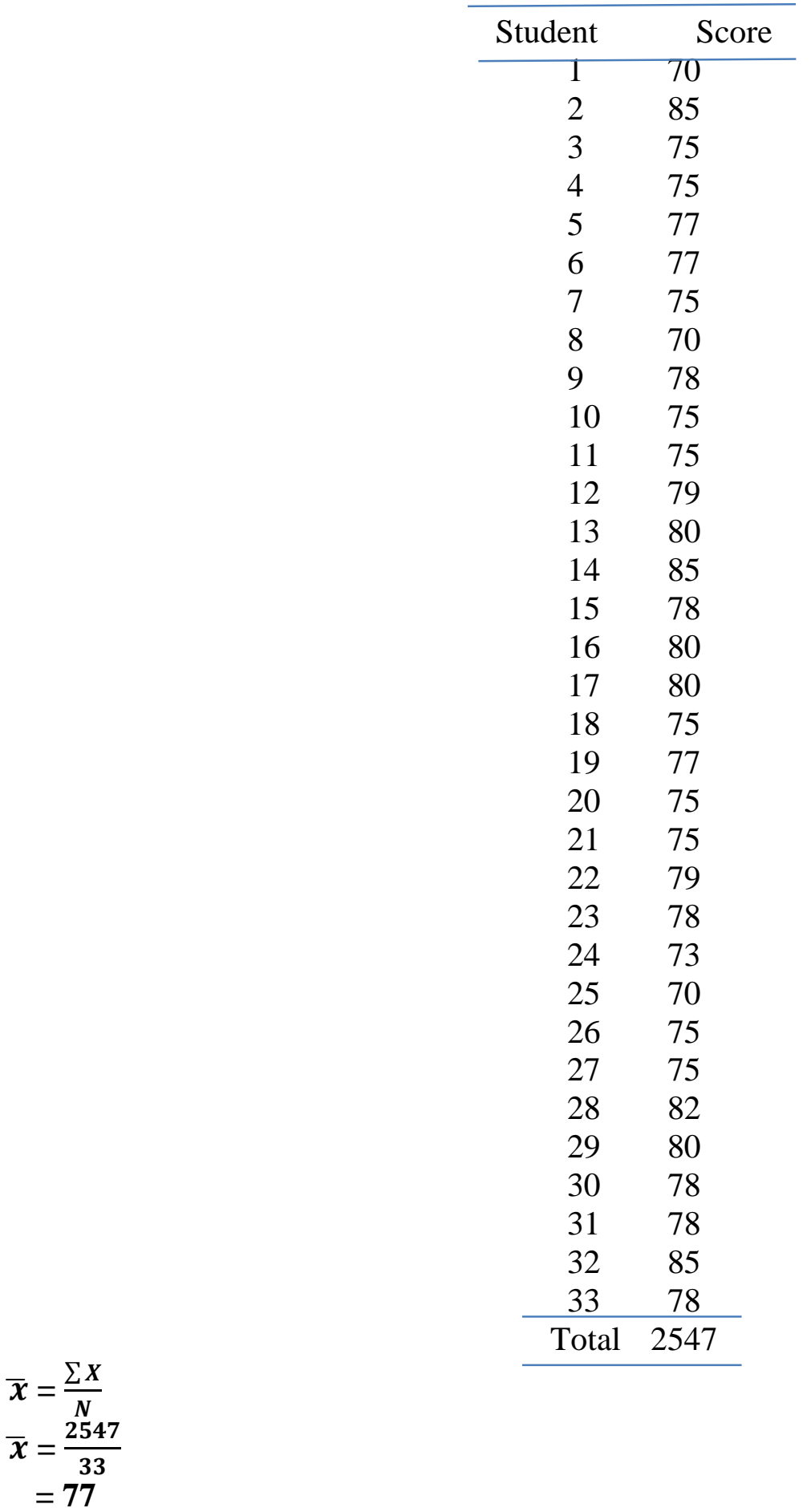


Based on the findings, students' mean scores increase in reading comprehension of analytical exposition text. The average score in the third cycle shows more than $70 \mathrm{KKM}$ values. The learning process in the third cycle also better than the first and second cycles. It means the research has succeeded and the cycle can be stopped.

\section{Discussion}

In this research, the writers using Classroom Action Research (CAR), which consists of 33 students at eleventh grade in SMA Mathla'ul Anwar. There are four steps in action research. Namely: planning, action, observation, and reflection". The writers used several procedures which is including steps in CAR. The writers implementing the learning model using the TPS technique with the steps of Thinking, Pairing, and Sharing. Based on the results of observations made at the time of the study, data were obtained on students' reading comprehension ability in the first, second and third cycles. Based on observations made on students, it is known that there is an increase in learning outcomes from the first cycle 59.6 to 67.5 on the second and the third cycle is 77. Thus the learning of reading comprehension skills using the think-pair-share technique at Mathla'ul Anwar High School has succeeded.

\section{CONCLUSION}

Based on the discussion above, the use of the think-pair-share method has improved students' reading comprehension. The students' score of analytical exposition is increased. There is an improvement in every cycle, the third cycle is better than the first and second cycle. So, it can be concluded that the application of the think-pair-share (TPS) technique at the eleventh grade of SMA Mathla'ul Anwar is effective for improving reading comprehension of analytical exposition.

\section{ACKNOWLEDGMENTS}

First of all the writers would like to thank to Allah SWT for giving the opportunity to work on this journal, the second is the writers would like to express thanks to The Head Master of SMA Mathla'ul Anwar, for his permission to conduct the research, the third is the writers would like to express thanks to our lecturer for all guidance, and advice so that we can complete and publish our journal.

\section{REFERENCES}

abdurrahman Usman. (2015). Using The Think-Pair-Share Strategy To Improve Students Speaking Ability At Stain Ternate. Journal Of Education And Practice, 6(10), 37-46.

Anjuni, Gian Reka, And Roby Cahyadi. 2019. "Improving Students ' Reading Comprehension Through Sq3r ( Survey, Question, Read, Recite, And Review ) Technique." 2(1)

Apsari, Y., \& Yana, Y. (2015). Teachers'techniques And Problems In Teaching Reading. P2m Stkip Siliwangi, 2(2), 217-233.

Burns, A. (2010). Doing Action Research In Eng Lang Teaching. Https://Doi.Org/10.1016/J.System.2010.06.005

Mundriyah, M., \& Parmawati, A. (2016). Using Think-Pair-Share (Tps) To Improve Students'writing Creativity (A Classroom Action Research In The Second Semester Students Of Stkip Siliwangi Bandung). P2m Stkip Siliwangi, 3(2), 84-91.

Purnomo, S. (2012). Improving Students ' Reading Comprehension. 2(2), 37-44. 
Rohman, F. (2017). The Effectiveness Of Think - Pair - Share Technique (Tps ) To Teach Reading Islamic Education And Teacher Training Faculty.

Sapsuha, S., \& Bugis, R. (2013). Think Pair Share Technique To Improve Students' Reading Comprehension. Jurnal Jupiter, 13(2), 101-111.

Objectives, Student Learning. 2016. "Quantitative Research Methods."

Williams, Carrie. 2007. "Research Methods." 5(3): 65-72. 